\title{
SEASONAL VARIATIONS OF ZOOPLANKTON, CHLOROPHYLL-A AND NUTRIENTS IN PHEWA LAKE, POKHARA VALLEY, NEPAL
}

\author{
Md. Akbal Husen and Ram Prasad Dhakal \\ Fisheries Research Centre \\ PO Box 274, Begnas, Kaski, Nepal \\ Email: akbalhusen@yahoo.com
}

\begin{abstract}
In order to understand trophic status of lake Phewa, largest lake (535 ha) in Pokhara valley, seasonal pattern of zooplanktons, chlorophyll $a$ and nutrients level in water column was examined from January to December 2005. Total zooplanktons density was highest in January and November, showed bimodal pattern in Lake Phewa. The sequence of dominant species of zooplankton was Nauplius > Kerratella > Cyclops > Daphnia > Eodiaptomus in this lake. Correlation between zooplankton species and nutrients level was established. The Chlorophyll- $a$ as an indicator of phytoplankton biomass peaks in November and chlorophyll-a concentration was found lower in winter months. The $\mathrm{NH}_{4}-\mathrm{N}$ ranged between zero to $0.021 \mathrm{mg} / \mathrm{l}$ with mean of $0.003 \mathrm{mg} / \mathrm{l}$. The annual concentration of nitrate+nitrite $\left(\mathrm{NO}_{3}+\mathrm{NO}_{2}\right)$ was found upto $0.148 \mathrm{mg} / \mathrm{l}$ (mean= $0.013 \mathrm{mg} / \mathrm{l}$ ), soluble reactive phosphate $\left(\mathrm{PO}_{4}-\mathrm{P}\right)$ ranged from zero to $0.003 \mathrm{mg} / \mathrm{l}$ (mean= $\left.0.001 \mathrm{mg} / \mathrm{l}\right)$, and total phosphorous ranged upto $0.052 \mathrm{mg} / \mathrm{l}$ (mean= $0.009 \mathrm{mg} / \mathrm{l}$ ) in lake Phewa in 2005. Based on nutrients and chlorophyll-a dynamics, the lake varied from mesotrophic to eutrophic in different seasons. The Phewa Lake fluctuated from oligo-mesotrophic in monsoon seasons to meso-eutrophic in dry periods.
\end{abstract}

Key words: Zooplanktons, nutrients, chlorophyll.

\section{INTRODUCTION}

Phewa lake (742 masl) is the biggest lake in Pokhara valley. The lake water is used mainly for irrigation, drinking, recreation as well as fish culture. Total fish production in Phewa lake reached about $98 \mathrm{~m}$ in 2001 contributing up to 219 kg.ha $\mathrm{y}^{-1} \mathrm{y}^{-1}$ (Gurung et al. 2005). There are 23 native fish reported in Phewa lake. The fishery in Phewa lake is comprised of exotic and indigenous fishes with substantial contribution of the former (Wagle and Bista 1999).

Zooplanktons are minute organisms which float in the water surface along with water current. They occupy an intermediate position in the food web. The importance of zooplanktons as fish food both for adults and fry has been stressed by different workers (Fontaine and Revera 1986 and Geiger 1983). The presence and dominance of 
zooplankton species play very significant role in the functioning of fresh water ecosystems. The seasonal changes in zooplankton species are closely related to the physico-chemical and biological regime of the aquatic environments. Species of Rotifer and Cladocerans are suggested as indicators that can be used to identify different physical and chemical gradients or eutrophic increases in reservoirs (Branco et al. 2002). The relation of zooplanktons to phytoplanktons and other physical and chemical gradients are well described. So seasonal variation of zooplanktons may be a key factor to understand the lake ecosystem. A considerable number of studies have been done on zooplanktons dynamics in lakes of Pokhara valley (Ferrro 1983, Bayne et al. 1992, Mulmi and Rai 1988, Rai 2000). However, the relation between nutrient dynamics and abundance of zooplanktons has not been studied in Phewa lake. Therefore, this paper deals with spatial and temporal distribution of nutrients and zooplankton in Phewa lake. The relation between nutrients and secondary trophic level in the lake and their significance for the lake ecosystem management is also discussed.

\section{STUDY AREA}

Lake Phewa watershed is located in southwest of Pokhara valley, Nepal. The surface area, water volume, maximum and average depth of the lake are $5.23 \mathrm{~km}^{2}, 39.32 \times 10^{6} \mathrm{t}, 24 \mathrm{~m}$ and $7.5 \mathrm{~m}$, respectively. Harpan khola flowing from the west to east is the main perennial stream to the lake and sometimes water flows from a canal of Seti river but not enough to fill up the lake. The rain water is the main source. For the present study, northwestern shore (Khapaudi) of the lake was selected for water and zooplankton sampling. Cage fish culture is the main activity in inshore water and fisher community settled along the basin of this site.

\section{MATERIALS AND METHODS}

Water samples for physical, chemical and biological parameters were collected monthly from January to December 2005. Water samples were taken from 0 (surface), 2.5, 5.0. 7.5 and $10.0 \mathrm{~m}$ depth in Phewa lake for each parameter except zooplanktons. All the samples were collected using Vandorn water sampler of 3 liter capacity. The parameters examined were zooplanktons, dissolved oxygen, $\mathrm{pH}$, temperature, transparency, and soluble reactive phosphorus, total phosphorus (TP), nitrate and nitrite. Water temperature and $\mathrm{pH}$ ware measured in field using thermometer and SIBATA pH kit, respectively. Chl-a samples were obtained from $1000 \mathrm{ml}$ integrated samples and 300 $\mathrm{ml}$ filtered through GF/c (whatman $47 \mathrm{~mm}$ ) filter paper. This filtered water was used for the $\mathrm{NH}_{4}-\mathrm{N}$, $\mathrm{PO}_{4}-\mathrm{P}$, and $\mathrm{NO}_{2}+\mathrm{NO}_{3}$ determination. The chlorophyll concentrations were determined according to methods by Lorenzen (1977). The SRP concentration was estimated by the methods described by Murphy and Riley (1962). Nitrate and nitrite concentration was estimated by the method described by Downes (1978). The ammonium concentration was estimated by the methods described by Bower and Hansen (1980). The water transparency was measured with a $20 \mathrm{~cm}$ diameter black and white secchidisk. Zooplankton samples were obtained by passing 101 water through plankton net in each depth. Zooplankton samples were anesthetized with $3 \%$ procaine and preserved in 5\% formalin. Enumeration of zooplanktons and analysis were done by the methods in laboratory manual of water quality analysis by Masuda and Pradhan (1988). 


\section{RESULTS}

The annual range of water quality parameters are presented in Table 1.

Table 1. Annual mean and range of limnological parameters

\begin{tabular}{lcc}
\hline Parameters & Mean \pm SD & Range \\
\hline Temperature $\left({ }^{\circ} \mathrm{C}\right)$ & $22.8 \pm 4.01$ & $16.5-30.0$ \\
Transparency & $2.6 \pm 0.56$ & $1.7-3.8$ \\
pH & $6.6 \pm 0.39$ & $5.8-7.3$ \\
D.O. $(\mathrm{mg} / \mathrm{l})$ & $5.6 \pm 2.98$ & $0.0-9.7$ \\
Chlorophyll-a & $13.5 \pm 16.29$ & $0.0-99.1$ \\
$\left(\mathrm{mg} / \mathrm{m}^{3}\right)$ & & \\
$\mathrm{NH}_{4}-\mathrm{N}(\mathrm{mg} / \mathrm{l})$ & $0.003 \pm 0.00$ & $0.000-0.021$ \\
$\mathrm{NO}_{3}+\mathrm{NO}{ }_{2}(\mathrm{mg} / \mathrm{l})$ & $0.013 \pm 0.03$ & $0.000-0.148$ \\
$\mathrm{PO} 4-\mathrm{P}(\mathrm{mg} / \mathrm{l})$ & $0.001 \pm 0.00$ & $0.000-0.003$ \\
$\mathrm{~T} . \mathrm{P} .(\mathrm{mg} / \mathrm{l})$ & $0.009 \pm 0.01$ & $0.000-0.052$ \\
Rotifer $(\mathrm{No} . / \mathrm{l})$ & $126 \pm 120.5$ & $0-556$ \\
Cladocera $(\mathrm{No} . / \mathrm{l})$ & $23 \pm 50.7$ & $0-385$ \\
Copepods $(\mathrm{No} . / \mathrm{l})$ & $317 \pm 283.6$ & $39-2008$ \\
Total zooplanktons & $465 \pm 360.8$ & $45-2148$ \\
(No./l) & & \\
\hline
\end{tabular}

\pm Standard deviation

The pattern in water temperature was typical of monomictic lakes. With increasing day length from spring to summer water temperature increased at surface layer. The maximum mean water temperature at surface layer was $28.7^{\circ} \mathrm{C}$ in August while lowest was $17.3^{\circ} \mathrm{C}$ in February. From summer to fall, the thermocline slowly moved to deeper layer and became highest $\left(25^{\circ} \mathrm{C}\right)$ in July while lowest was in February $\left(16.8^{\circ} \mathrm{C}\right)$. Water temperature started to decline after September and reached about $18^{\circ} \mathrm{C}$ in December at both layers during the holomixing at the water column. March onwards when temperature begins to rise with increasing day length and the lake stratified from March to September. Contrastingly, in winter the water temperature was almost similar in all depths from November-February. Maximum difference of water temperature observed between two layers was $5^{\circ} \mathrm{C}$ in June.

The transparency from March to November was inconsistent however, after November visibility increased consistently through out the winter. The mean transparency during the study period was $2.6 \mathrm{~m}$. The highest transparency recorded in March was $3.8 \mathrm{~m}$ and lowest was $1.7 \mathrm{~m}$ in November.

Comparing the two layers, the dissolved oxygen was always higher at the surface layer. The highest variations between two layers were observed from March to November during the lake stratification periods. The lowest dissolved oxygen (DO) in upper layer was $4.7 \mathrm{mg} / \mathrm{l}$ in November, while highest was $9.5 \mathrm{mg} / \mathrm{l}$ in February, in the bottom layer the minimum reached to $0.1 \mathrm{mg} / 1$ in May and maximum was $8.8 \mathrm{mg} / \mathrm{l}$ in February. Well oxygenated bottom was recorded with onset of winter from December to February. After February the dissolved oxygen in the upper layer declined gradually till July and fluctuate from August to January. It was December when both layers had equal value of dissolved oxygen.

The $\mathrm{pH}$ value was higher in upper layer and almost closest value found from December to February at both layers.

The Chlorophyll-a peak was found in November at both layers of water column. The highest concentration in upper layer was 70.4 $\mathrm{mg} / \mathrm{m}^{3}$ and that of bottom layer was $30.0 \mathrm{mg} / \mathrm{m}^{3}$ in November. The lowest Chlorophyll-a concentration at upper layer was $2.3 \mathrm{mg} / \mathrm{m}^{3}$ in July and in bottom layer it was $1.1 \mathrm{mg} / \mathrm{m}^{3}$ in January. The upper layer has higher concentration of Chlorophyll-a from January-May. The concentrations of Chlorophyll a were higher in both layers from April-June and SeptemberNovember. The average of both layers showed 
lower concentration of chlorophyll a during June to September.

Comparing both layers, bottom layer had higher concentration of ammonium $\left(\mathrm{NH}_{4}-\mathrm{N}\right)$. It was January when peak of ammonium was found in both layers. Upper layer concentration was $0.019 \mathrm{mg} / \mathrm{l}$ and bottom layer was $0.014 \mathrm{mg} / \mathrm{l}$.The variation of concentration of ammonium was observed from March to October when the lake is stratified. In April and September the concentration of Ammonium was negligible.

The maximum concentration of nitrite + nitrate was $0.115 \mathrm{mg} / \mathrm{l}$ in upper layer and $0.066 \mathrm{mg} / \mathrm{l}$ in bottom layer in February. The concentrations of nitrite + nitrate fluctuate during the lake stratification period from March to September and remain consistent from October to January.

In general higher concentration of soluble reactive phosphorus (SRP) was observed in bottom layer of lake column. The upper layer had higher concentration of SRP from November to December and bottom layer had higher concentration of SRP during January to October.

Concentration of total phosphorus (TP) was higher in bottom layer of lake from March to October when lake is stratified. In upper layer, higher concentration of TP was found in JanuaryFebruary and in November. In December, when holomixing of water column in lake takes place, same amount of TP concentration occurs in both layers. The peak of total phosphorus concentration was observed in January at upper layer (0.021 $\mathrm{mg} / \mathrm{l}$ ) and at bottom layer highest concentration was found in March $(0.037 \mathrm{mg} / \mathrm{l})$ The lowest concentration of TP was in both layers in August.

Seasonal abundance of dominant zooplankton species is presented in Table 2 .
Table 2. Seasonal abundance of zooplanktons (dominant species) in lake Phewa.

\begin{tabular}{lccc}
\hline Zooplankton Species & Summer & Monsoon & Winter \\
\hline Kerratella sp. & +++ & +++ & +++ \\
Brachionus sp. & ++ & + & ++ \\
Trichocera sp. & + & + & + \\
Synchaeta sp. & - & - & ++ \\
Filinia sp. & + & + & ++ \\
Polyarthra sp. & + & + & + \\
Bosmina sp. & + & + & + \\
Daphnia sp. & + & ++ & ++ \\
Pleuroxus sp. & - & - & - \\
Nauplius $\mathrm{sp}$. & ++ & +++ & +++ \\
Cyclops $\mathrm{sp}$. & ++ & +++ & ++ \\
Eodiptomus $\mathrm{sp}$. & ++ & ++ & + \\
\hline
\end{tabular}

0 absent (-), 1-10 N/L low (+), 10-40N/L medium (++), over 40 N/L highest (+++)

Twenty species of zooplanktons were recorded throughout the study periods, out of which 10 species were from class Rotifer, 6 species from class Cladocera and 4 species belong to class Copepods. The annual mean percentage composition of classes were: Rotifer $27 \%$, Cladocera $4 \%$ and Copepodes $68 \%$. Class Copepods dominate in Phewa lake followed by Rotifer and Cladocerans. The sequence of dominant species was Nauplius > Kerratella > Cyclops $>$ Daphnia $>$ Eodiptomus $>$ Brachionus $>$ Trichocerca $>$ Synchaeta $>$ Filinia $>$ Polyarthra $>$ Bosmina.

Total zooplanktons density attained peak in January (831 individuals/l) and November (832 individuals/l) showing bimodal pattern in lake Phewa (Fig. 1). The zooplanktons density declines after March till June reaching to their lowest density and consistent from July to September and increased from October to January. The upper layer of lake Column had higher number of zooplanktons density from April to October when lake is stratified, and bottom layer had higher 
density of zooplanktons from November to March. The class Rotifer attained their highest density in November and lowest density in July. The class Cladocera attained highest density in January and lowest density in May. The class Copepods attained highest density in March and lowest in May.

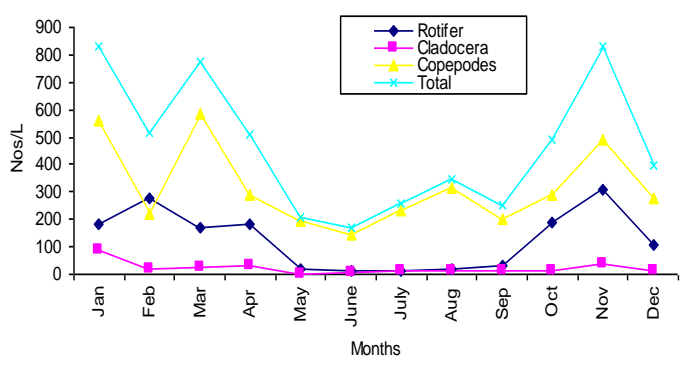

Fig. 1. Seasonal variation of zooplankton classes and total zooplanktons in lake Phewa.

The patterns of most dominated species of zooplanktons were different. The Nauplius showed their peaks in March while lowest density was found in June. Kerratella species peaked in November and lowest density was observed in August. Cyclops attained maximum density in July and minimum density in January. Daphnia species density was highest in January and lowest in June.

Regression analysis was done to find out relationship of zooplanktons with other variables. Rotifer was inversely co-related to water temperature. Filinia and Daphnia species were inversely correlated to transparency and Kerratella species was positively correlated to total phosphorus. Kerratella species was associated with temperature. Inverse correlation found between Brachionus species and temperature. Rotifer was positively related with decline of chlorophyll-a. The seasonal change in zooplankton species was closely related to the physico-chemical and biological regime of the aquatic environments

\section{DISCUSSION}

Total zooplankton density peak showed bimodal pattern in lake phewa. The density of zooplanktons declined in June once through out the year. Vassiht and Sharma (1975), Gophen (1972), and Wangaeno (1980) reported bimodal pattern of zooplanktons peak in freshwaters. The lower density of zooplanktons during the spring to summer coincides to Plankton Ecology Group model (Sommer et al. 1986) cited by Bronmark and Hanssen (1998). The reason stated PEG model that in summer herbivorous zooplanktons face food limitation and fish predation increases due to higher temperature and development of young fish, leading to a reduction in size and abundance of zooplanktons.

Transparency was low in November, associated with blooms of phytoplanktons. Similar to Rai (2000), the dominance of Ceratium hirrudenela and Peridinium species was observed in Phewa lake during November. The decline of chl-a in March is explained by PEG model, Sommer et al. (1986) showed that in spring, grazing rate exceeds phytoplankton's production rate, leading to a reduction in algal biomass. The chl-a amount depends upon the phytoplanktons available but directly affected with rainfall and water flush out.

The chlorophyll-a concentration was low in winter months (December to January). Despite of lengthy photoperiod and summer irradiation, chlorophyll-a concentration was lower during the summer monsoon. This evidently suggests the flushing of lake water or dilution by strong rain water, preventing phytoplankton's growth density.

Bottom Layer showed higher concentration of ammonium than upper layer might be due to low level of oxygen in bottom layer.

Species of Rotifer and Cladocerans are suggested as indicator that can be used to identify different physical and chemical gradients in 
reservoirs (Branco et al. 2002). The relation of zooplanktons to phytoplanktons and other physical and chemical gradients are well described.

\section{TROPHIC CONDITION OF LAKE}

Several studies have revealed the mesotrophic status of lake Phewa (Ferro 1980, Fleming 1981, Nakanishi et al. 1998, Davis et al. 1998). Presently, lake is facing severe environmental problems as a result of nutrient loading from agriculture, landslides, and rapid urbanization in the surrounding areas. Recent trends indicate rapid eutrophication (Oli 1997, Rai 2000). However, the lake is seasonally oligotrophic due to heavy rainfall in its wider catchment area (Rai 2000). In the present study lake varied to oligo-eutrophic condition. In the monsoon periods, the concentrations of ammonium, Chlorophyll a and zooplanktons were low. It suggests oligotrophic to mesotrophic condition of lake. While other months showed mesotrophic to eutrophic condition of lake.

According to the classification of Wetcel (1983), Chlorophyll-a concentrations of Phewa Lake range $0-99.1 \mathrm{mg} / \mathrm{m}^{3}$ with average $13.5 \mathrm{mg} / \mathrm{m}^{3}$ is under eutrophic. Phewa lake transparency range 1.7-3.8 $\mathrm{m}$ with average value $2.6 \mathrm{~m}$ is under mesotrophic to eutrophic. Phewa lake T.P. concentrations range $0.000-52 \mu \mathrm{g} / \mathrm{l}$ and average 6 $\mu \mathrm{g} / \mathrm{l}$ is under oligotrophic to mesotrophic.

According to Mackie et al. 2000, Mackie 2004, total phosphorus range, Chlorophyll-a range and Secchidisc depth range (Table 1) indicate Phewa lake as oligo-eutrophic, eutrophic and meso-eutrophic, respectively. According to Bronmark and Hansson (1998), the pattern of zooplanktons represents the eutrophic condition of lake.

\section{ACKNOWLEDGEMENTS}

The authors thank Dr. Tek Bahadur Gurung, Station Chief, Suresh Kumar Wagle and J.D. Bista for guidance, and junior technicians for cooperation in limnological survey.

\section{REFERENCES}

Bayne, D.R., A.K. Rai, P.L. Joshi and J.C. Williams. 1992. Limnological factors influencing growth of cage cultured bighead carp female Silver carp male Hybrids. Jour. Appli. Aquaculture. 4:29-49.

Bower, C. E. and Holm-Hansen. 1980. Can. J. Fish. Aquat. Sci. 37:794-798.

Branco, C.C., Mariea Isabel, A. Rocha, Glaucia, F.S. Pinto, Giesele A. Gomaro and Rodrigo de Filippo. 2002. Limnological features of Funil reservoirs (R.J. Brazil) and indicator properties of rotifers and cladocerans of the zooplankton community of lakes and reservoirs. Res. and Manag. 7:187-192.

Bronmark, C. and L. Anders Hansen. 1998. The Biology of Lakes and Ponds. Oxford University Press, UK, pp. 178-182.

Davis, M.F., T.B. Gurung, B.C. Shrestha, S.B. Jones, G.D. Wyle, B.D. Perkins and J.R. Jones. 1998. Use of surface plankton layer to benefit a cage culture fihsery in Phewa lake, Nepal. Verh. Internat. Verein. Limnol. 26:940947.

Downes, M.T. 1978. A modified single solution method for the determination of phosphate in natural waters. Water Res. 12:673-675.

Ferro, W. 1980. Data on the fishery of Pokhara valley and their implications for the fishery management. Journal of the Institute of Science. 3:225-236.

Ferro, W. 1983. Limnology of the Pokhara valley lakes and its implication for fishery and fish culture. Jour. Nep. Res. Cen. V/VI:27-52.

Fleming, W.M. 1981. Phewa Tal Management Program: benefits and cost of forestry and soil conservation In Asia and Pacific. In: Forest and Watershed Developments and 
Conservation in Asia and the Pacific. (ed.) Hamilton, I.S. Boulder. West View Press, Colorodo, pp. 217-288.

Fontaine, C.T. and D.B. Revera. 1986. The mass culture of rotifers, Branchionus plicatalis, for use as foodstuff in aquaculture. Proc. World Mariculture Soc. 11:211-218.

Geiger, J.G. 1983. A review of ponds zooplankton productions fertilization for the culture of larval and fingerlings. Aquaculture 36:353360.

Gophen, M. 1972. Zooplanktons distribution in lake Kinnaret (Israel). 1969-1970. Israel J. Zool. 21:17-27.

Gurung, T.B., S.K. Wagle, J.D. Bista, R.P. Dhakal, P.L. Joshi, R. Batajoo, P. Adhikari and A.K. Rai. 2005. Participatory fisheries management for livelihood improvement of fisheries in Phewa Lake, Pokhara, Nepal. Himalayan Journal of Sciences. 3(5):47-52.

Lohman, K.J., J.R.M.F. Knowlton, D.B. Swar, M.A. Pamphel and B.J. Brajosh. 1988. Preand post monsoon limnological characteristics of lakes in Pokhara and Kathmandu valley. Nepal Verch. Int. Ver. Limnology. 23:558-565.

Lorengen, C.J. 1977. Determination of chl-a and pheopigments spectrophotometer equation: limnology Oceanogr. 12:343-346.

Mackie, G.L. 2004. Applied Aquatic Ecosystem Concepts. Second Ed. Kendall/Hunt Publishing Company. 784 pp.

Mackie, G.L., S. Hincks and D. Barker. 2000. Introduction to Aquatic Environments. Course Manual, Univeristy of Guelph, Canada.

Masuda, K. and B.R. Pradhan. 1988. Laboratory manual of water quality analysis for fisheries technicians in Nepal, HMG, Fisheries Dev. Division. Harihar Bhawan, Kathmandu.
Mulmi, RM. and A.K. Rai. 1988. Seasonal abundance of zooplanktons in lakes of Pokhara valley, Present status of fisheries research and education in Nepal, NEFD project JICA. pp. 86-88.

Murphy, J. and J.P. Riley. 1962. Ana. Chim. Acta. 27:31 (modified by Stirckland and Parsons 1966).

Nakanishi, M., M.M. Watnabe, A. Terashima, Y. Soko, T. Konda, K. Shreshta, H. Bhandari and Ishiday. 1998. Studies on some limnological variables in subtropical lakes of Pokhara variables. Nep. Jap. J. limno. 49:71-86.

Oli, K.P. (ed.). 1997. Phewa lake conservation action plan, International Union For Nature Conservation (IUCN), Kathmandu, Nepal, 75 p.

Rai, A.K. 2000. Limnological characteristics of subtropical lakes Phewa, Begnas and Rupa in Pokhara Valley. Nepal Limnology. 1:1-13.

Sommer, U., Z.M. Gliwiccz, W. Lamper, A. Duncan. 1986. The PEG model of seasonal succession of planktonic events in fresh waters. Arch. Hydrobiol. 106:433-471.

Vasisht, H.S. and B.K. Sharma. 1975. Ecology of a typical urban pond in Ambala city of the Haryana. Ind. J. Ecology. 2(1):79-86.

Wagle, S.K. and J.D. Bista. 1999. Catch efforts and capture fishery in lakes of Pokhara valley:status and management perspective. In: Proceeding of $3^{\text {rd }}$ national workshops on livestock and fishery research in Nepal, Lalitpur, Nepal. (eds.) Neupane, S.P. and R.C. Khanal. Nepal Agricultural Research Council, Kathmandu, p. 53-69.

Wangaeno, A. 1980. Phytoplankton's Photosynthesis, Nutrients dynamics and trophic status of Manasbal lake, Kashmir. Ph.D. Thesis, Kashmir University, India.

Wetzel, R.G. 1983. Limnology (second edition), Saunsers College Publishing, 860 pp. 